\title{
Correction to: Political culture research: dilemmas and trends. Prologue to the special issue
}

\section{Camelia Florela Voinea ${ }^{1}$}

Published online: 16 December 2019

(c) Springer Nature B.V. 2019

\section{Correction to: Quality \& Quantity https://doi.org/10.1007/s11135-019-00943-0}

The original publication of the article includes error in the reference. In Section " 1 The classics and their heritage as suggested by the contemporary trends", the reference to "Welch (2013)" is replaced with the reference "Welzel (2013)" and the reference is provided in this correction.

\section{Reference}

Welzel, C.: Freedom Rising Human Empowerment and the Quest for Emancipation. Cambridge University Press, Cambridge (2013)

Publisher's Note Springer Nature remains neutral with regard to jurisdictional claims in published maps and institutional affiliations.

The original article can be found online at https://doi.org/10.1007/s11135-019-00943-0.

Camelia Florela Voinea

camelia.voinea@fspub.unibuc.ro

1 Department of Political Science, International Relations and Security Studies, European Research Centre for Political Culture, Faculty of Political Science, University of Bucharest, Bucharest, Romania 